\title{
НАЦІОНАЛЬНІ МЕНШИНИ В КОНТЕКСТІ ДЕРЖАВНОЇ ЕТНОПОЛІТИКИ ДОБИ ЗУНР
}

\author{
Микола ЛАЗАРОВИЧ \\ Тернопільський національний економічний університет, \\ кафедра документознавства, інформачійної діяльності та українознавства, \\ вул. Львівська, 11, 46009, Тернопіль, Україна \\ e-mail:lazar-m@ukr.net \\ DOI: $10.15330 / \mathrm{gal} .32 .48-54$ \\ ORCID: 0000-0002-8598-9019
}

\begin{abstract}
Метою статті є аналіз та узагальнення особливостей і тенденцій етнонаціональної політики влади ЗУНР в умовах визвольних змагань 1918-1919 рр. Досліджено основні заходи української влади стосовно забезпечення прав і свобод іноетнічного населення. Проаналізовано правові засади державної етнополітики. Визначено ставлення національних меншин до украйнського держсвотворення. Виснувано, щзо етнополітика керівництва ЗУНР була демократичною, однак характерною особливістю окресленого хронотопу були важкі умови, викликані агресією з боку Польщі. Тому чимало заходів украӥнської влади нерідко залишалися декларативними через неможливість їхньої реалізації. Певну непослідовність проявляли ци національні меншини, насамперед євреї й німиі, котрі, дотримуючись нейтралітету в польсько-українській війні, істотно обмежували свою участь у державотворчих процесах.
\end{abstract}

Ключові слова: органи влади, етнополітика, національна меншина, права і свободи, закони.

Без критичного осмислення й узагальнення минулих етнополітичних здобутків $\mathrm{i}$ прорахунків та їхнього наукового дослідження неможливо конструктивно вирішити сучасні міжнаціональні проблеми, прогнозувати й моделювати їхній розвиток у майбутньому. Вагомим підгрунтям для такої діяльності може стати політико-правовий досвід вирішення національних проблем в Україні періоду визвольних змагань 1917-1921 рр. Поліетнічність населення України передбачала вжиття заходів для забезпечення громадянських прав і свобод національних меншин, а також умов для їхньої етнокультурної самобутності та політичного розвитку. Таку діяльність, зокрема, послідовно здійснювали діячі Західноукраїнської Народної Республіки (ЗУНР).

Мета дослідження - аналіз та узагальнення особливостей і тенденцій етнонаціональної політики влади ЗУНР в умовах визвольних змагань 1918-1919 рр. Його завдання прослідкувати основні заходи української влади в забезпеченні прав і свобод іноетнічного населення; висвітлити правові засади державної етнополітики; визначити місце національних меншин в українському визвольному русі, їхнє ставлення до державотворчих процесів.

Означена проблема ще не повною мірою відображена у вітчизняній і зарубіжній історіографії, однак робота в даному напрямку ведеться. Серед сучасних досліджень насамперед слід виділити колективну монографію "Національні меншини України у XX ст.: політико-правовий аспект", "Малу енциклопедію етнодержавознавства", а також праці таких науковців, як В. Великочий, М. Гон, С. Коган, Ю. Котляр, М. Лазарович, С. Макарчук, О. Мироненко, О. Павлишин, Л. Рябошапко, В. Чехович та ін. ${ }^{1}$. Головним джерелом дослідження стали опубліковані документи ${ }^{2}$.

\footnotetext{
${ }^{1}$ Великочий В. Національно-культурна політика ЗУНР у контексті українсько-польських відносин (19181919). Міжнародний науковий конгрес “Украӥнська історична наука на порозі ХХІ ст." : Доповіді та повідомлення (Чернівці, 16-18 травня 2000 р.). Чернівці, 2001. Т. 2. С. 266-270 ; Гон М. Євреї в ЗУНР: стратегія, тактика та вплив на формування взаємин з українцями в міжвоєнний період. Украӥна : культурна спадщина, наџіональна свідомість, державність. 2009. Вип. 18. С. 181-189 ; Коган С. Евреи в
} 
ЗУНР охоплювала близько 70 тис. км² території з 6 млн населення (3 них 71\% українців, $14 \%$ поляків, $13 \%$ євреїв, $2 \%$ угорців, румунів та ін.). За віросповіданням було $62 \%$ грекокатоликів, $18 \%$ римо-католиків, 13\% юдеїв, 6\% православних. Проте після іноземної окупації Північної Буковини й Закарпаття, а згодом і частини Східної Галичини під управлінням уряду ЗУНР фактично залишалося не більше як 45 тис. км ${ }^{2} 3$ майже 4 млн населення (3 них 75\% українців, $12 \%$ поляків, $11 \%$ євреїв і $2 \%$ представників інших етносів) ${ }^{3}$. Тимчасовими органами влади ЗУНР стали: законодавчої - Українська Національна Рада (УНРада), виконавчої Державний Секретаріат.

Серед основних проблем молодої держави, які потребували термінового_вирішення, забезпечення прав і свобод іноетнічного населення, оскільки не рахуватися 3 тим, що його частка становила понад чверть людності ЗУНР, було неможливо. Так, ще 19 жовтня 1918 р., декларуючи утворення Української держави, новостворена УНРада своєю першою постановою проголосила визнання прав національних меншин, у т. ч. євреїв як нації, і гарантію їхньої національно-культурної автономії та їхнє представництво в уряді. Документом також прокламувалося прийняття конституції, розробленої “на основах загального, рівного, тайного і безпосереднього права голосування 3 пропорціональним заступством, 3 правом національнокультурної автономії та 3 правом заступства при правительстві для національних меншостей”4. 3 огляду на це 1 та 5 листопада 1918 р. тимчасовий законодавчий орган підтвердив громадянську, національну й віросповідну рівноправність етнічних спільнот Української держави, закликав їх організуватися в окремі публічно-правові групи та направити до УНРади своїх представників ${ }^{5}$. Про це саме йшлося в Програмовій заяві Державного Секретаріату до громадян держави ${ }^{6}$ оприлюдненій у січні 1919 p.

Згідно зі Статутом повітових органів УНРади, виданим тимчасовим законодавчим органом у Львові в перші дні правління, одне 3 головних завдань українських повітових комісарів полягало в забезпеченні цивілізованих міжнаціональних відносин: “...поучити народ, щоби прихильно відносився до жидів і німецьких колоністів та не допускав до погромів, бо викликанє безладдя лежить в інтересі ворогів"7. Про ставлення до найбільшої національної меншини - поляків у документі не йшлося.

Западно-Украинской Народной Республике. Там само. С. 190-198 ; Котляр Ю. В. Етнонаціональні питання в Західно-Українській Народній Республіці. Там само. С. 175-180 ; Макарчук С. А. Українська Республіка галичан: нариси про ЗУНР. Львів : Світ, 1997. 192 с. ; Лазарович М. В. Етнополітика української влади доби національно-визвольних змагань 1917-1921 років: компаративний аналіз : монографія. Тернопіль : ТНЕУ, 2013. 760 с. ; Мироненко О. Національні меншини у ЗУНР. Мала енииклопедія етнодержавознавства. Київ : Довіра ; Генеза, 1996. С. 332 ; Павлишин О. Сврейське населення Східної Галичини у 1918-1919 рр.: соціальний аспект. Галичина. 2006-2007. Вип. 12-13. С. 27-48 ; Павлишин О. Організація цивільної влади ЗУНР у повітах Галичини (листопад-грудень 1918 р.). Україна модерна. 1999. Ч. 2-3. С. 132-193 ; Рафальський О. О. Національні меншини України у ХХ столітті : історіограф. нарис. Київ : Полюс, 2000. 447 с. ; Рябошапко Л. І. Правове становище національних меншин в Україні (1917-2000) : монографія. Львів : Вид. центр ЛНУ ім. І. Франка, 2001. 484 с. ; Чехович В. Конституція Західноукраїнської Народної Республіки. Мала енциклопедія етнодержавознавства. Київ : Довіра ; Генеза, 1996. С. 203-204 ; Чехович В. Національно політика уряду ЗУНР. Там само. С. 325-326 ; Klimecki M. Polsko-ukrainska wojna o Lwow i Galicje Wschodnia 1918-1919. Warsawa : Oficyna Wydawnicza Volumen, 2000. $292 \mathrm{~s}$

2 Західно-Українська Народна Республіка. 1918-1923. Док. і матер. : у 5 т. Івано-Франківськ : Лілея-НВ, 2001. Т. 1. 584 с. ; Західно-Українська Народна Республіка. 1918-1923. Док. і матер. : у 5 т. Івано-Франківськ: Лілея-НВ, 2003. Т. 2. 712 с. ; Західно-Українська Народна Республіка. 1918-1923. Док. і матер. : у 5 т. Івано-Франківськ : Лілея-НВ, 2005. Т. 3, кн. 2. 680 с. ; Національні меншини України у ХX ст.: політико-правовий аспект / М. Панчук, В. Войналович, О. Галенко та ін. Київ, 2000. 357 с.

${ }^{3}$ Чехович В. Національно політика уряду ЗУНР... С. 325.

${ }^{4}$ Західно-Українська Народна Республіка. 1918-1923. Док. і матер. : у 5 т ..... Т. 1. С. 181.

${ }^{5}$ Там само. С. $245,336$.

${ }^{6}$ Західно-Українська Народна Республіка. 1918-1923. Док. і матер. : у 5 т. ... Т. 2. С. 145.

${ }^{7}$ Там само. С. 12. 
Практично не зволікаючи, УНРада на пропозицію голови Державного Секретаріату К. Левицького 18 листопада 1918 р. ухвалила утворити в складі останнього три секретаріати: польський, єврейський і німецький. Їх мали очолити представники відповідних національних меншин краю", котрі “"з уряду мали стерегти, щоби правом застережені права їх націям були виконувані" ". Передумовою представництва меншостей в уряді мало стати їхнє представництво в Раді. 3 огляду на це вони мусили насамперед "потворти відповідні національні організації, котрі висловлювали би їх волю, після чого УНРада не відмовиться увійти з ними в порозуміння щодо відповідного заступництва в Раді й Державнім Секретаріяті"10.

Проте заклики вищих владних інституцій ЗУНР до політичних представницьких сил національних меншин брати участь у державотворчих процесах загалом не знайшли серед них бажаного розуміння. Це виявилося у тому, що фактично жодна 3 неукраїнських політичних партій чи громадських організацій не виявила бажання взяти відповідальність за формування й становлення ЗУНР, вироблення внутрішньо- та зовнішньополітичного курсу держави, відмовляючись увійти до її владних структур.

Мотиви такого ставлення політичних сил іноетнічного населення до ЗУНР були різними: від органічного неприйняття й протиборства - до конструктивного нейтралітету й персонального співробітництва. Перше, зокрема, чітко виявилося в діяльності польських політичних сил, які своїм основним завданням вважали відновлення власної незалежної національної держави. Західноукраїнські землі - Галичину, Волинь, Підляшшя і Холмщину - вони трактували як невід'ємну складову частину Польщі й тому намагалися будь-що їх інкорпорувати ${ }^{11}$. Представники єврейської й німецької меншин ще в першій половині дня 1 листопада 1918 р. висловили свої симпатії новопосталій Українській державі та попросили в iï керівництва захистити їхні права ${ }^{12}$. Однак в українсько-польському конфлікті і євреї, і німці дотримувалися нейтралітету, i, щоб не втягуватися в конфронтацію між найбільшими етносами краю, не брали участі у державному житті. Хоча було немало прикладів їхніх виступів на боці як українців, так i поляків ${ }^{13}$. Приміром, окремі 3 них зайняли урядові посади, чимало євреїв і німців служило в Українській галицькій армії та правоохоронних органах краю, працювало в освіті, медицині, зв'язку, на залізниці тощо.

Уряд ЗУНР не дискримінував працівників за національною ознакою. Поляки, євреї, німці, представники інших етносів могли залишатися на своїх посадах чи влаштуватися на будь-яку іншу роботу, якщо тільки присягнули на вірність Українській державі або зобов'язувалися не чинити їй ніякої шкоди ${ }^{14}$. Найскладнішими були відносини 3 польським населенням, частина якого спочатку зайняла стосовно української влади “поставу пасивної лояльності". Однак чимало поляків навіть не припускали думки про історичне право українців на Східну Галичину. Зокрема, більшість польських учителів та інших категорій інтелігенції не склали присяги на вірність ЗУНР. Проте уряд ЗУНР усе ж прагнув заручитися в польського населення якщо не підтримкою, то лояльним ставленням до української влади ${ }^{15}$. Насамперед це стосувалося тих місцевостей, де поляки становили значну частину.

Незважаючи на інертність та небажання національних меншин, УНРада не припиняла практичних спроб залучити їх до державотворчого процесу. Так, ухвалений нею 15 квітня

\footnotetext{
8 Західно-Українська Народна Республіка. 1918-1923. Док. і матер. : у 5 т ..... Т. 2. С. 30, 35.

9 Західно-Українська Народна Республіка. 1918-1923 : ілюстр. історія. Львів ; Івано-Франківськ : Манускрипт, 2008. С. 240.

10 Західно-Українська Народна Республіка. 1918-1923. Док. і матер. : у 5 т. ... Т. 2. С. 31.

${ }^{11}$ Великочий В. Національно-культурна політика ЗУНР у контексті українсько-польських відносин... C. 267.

${ }_{12}$ Західно-Українська Народна Республіка. 1918-1923. Док. і матер. : у 5 т. ... Т. 1. С. 256.

${ }^{13}$ Гон М. Євреї в ЗУНР: стратегія, тактика та вплив на формування взаємин з українцями в міжвоєнний період... С. 181-182 ; Західно-Українська Народна Республіка. 1918-1923. Док. і матер. : у 5 т. ... Т. 1. С. 285 ; Коган С. Евреи в Западно-Украинской Народной Республике... С. 193-194.

${ }_{14}$ Західно-Українська Народна Республіка. 1918-1923. Док. і матер. : у 5 т. ... Т. 2. С. 6, 41 ; Чехович В. Національно політика уряду ЗУНР... С. 325.

${ }^{15}$ Макарчук С. А. Українська Республіка галичан: нариси про ЗУНР... С. 143.
} 
1919 р. закон "Про Сойм" передбачав, що вищий законодавчий орган держави складатиметься “з 226 послів: української народности 160, польської 33, жидівської 27, і німецької 6, вибраних на основі загального, рівного без ріжниці пола, тайного, безпосереднього і пропорціонального виборчого права"16 (у відсотках національне представництво в парламенті виглядало так: українці $-70,8 \%$, поляки $-14,6 \%$, євреї - $11,9 \%$, німці $-2,7 \%{ }^{17}$ ). Такий принцип національнопропорційного представництва було визначено відповідно до національного складу населення Східної Галичини (інші західноукраїнські землі на той момент уже були окуповані) за переписом 1910 p. $^{18}$. Він гарантував більш чисельним національним меншинам можливість мати своїх представників у парламенті.

Важливим був також Закон про вибори до Сойму ЗУНР. Відповідно до нього територію держави поділили на 12 українських виборчих округів, 5 польських і єврейських, 1 - німецький ${ }^{19}$. Кількість послів від кожного з них була різною, і залежала від кількості виборців. Останні могли голосувати лише за представників своєї національності. Депутатів-українців передбачалось обрати в таких українських виборчих округах: Львівському - 22, Станіславівському - 20, Коломийському - 14, Золочівському і Самбірському - по 13, Перемишльському, Бережанському, Чортківському, Стрийському і Буковинському - по 12, Сяноцькому і Тернопільському - по 9. Депутатів польської і єврейської національності: Тернопіль-ЗолочівБережани - 10 поляків і 6 євреїв; Самбір-Сянок-Перемишль - 9 і 5; Львів - 7 і 7; СтаніславівСтрий-Чортків - 6 і 7; Коломия-Буковина - 1 поляк і 4 євреї. Шість депутатів-німців мали обиратися від усієї ЗУНР 20 . Оцінюючи цей виборчий закон, науковці ${ }^{21}$ зазначають, що такого демократичного на державному рівні забезпечення прав національних меншин при виборах законодавчих органів не знала світова виборча практика не тільки в той час, а й у наші дні.

Обидва закони стали не лише важливим внеском в українське законодавство. 3 їх прийняттям, стверджував один із дослідників історії ЗУНР М. Чубатий, було "усунено міжнаціональну боротьбу та можність державної нації загарбати мандати національної меншости"22.

У зазначеному ракурсі тривала й перебудова судової системи. Для національних меншин було встановлено квоту, щоб вони мали гарантовану можливість обирати своїх суддів. Якщо українцям належало право обрати 102 суддів, то полякам -25, євреям $-17^{23}$. Однак через польську окупацію в першій половині липня 1919 р. території ЗУНР ні згаданим законам, ні низці інших нормативно-правових актів так і не судилося бути реалізованими.

Разом із тим, несхитна позиція уряду ЗУНР на підтримку національних меншин отримала продовження і в еміграції, наприклад в підготовлених там проектах конституції ${ }^{24}$. Зокрема, в “Проекті Основ державного устрою Галицької Республики”, запропонованому найвищій Раді та Лізі Націй 30 квітня 1921 p. ${ }^{25}$, західноукраїнський провід пішов ще далі шляхом інтернаціоналізації державного політичного устрою. Так, у ст. III (“Державні народности”), в артикулі 3 зазначено: "В Галицькій Республиці узнається отсі три головні народности: українська, далі польська і жидівська. Вони користуються рівними правами на области публичного життя. Прочі народности в державі творять національні меншости, та їх права і охорону запоручує конституція”. У ст. VI, артикул 10: “Новообрана Державна Рада вибирає 3-поміж послів Президента Державної Ради і 4-ох віце-президентів. Президент Державної Ради має бути української

\footnotetext{
16 Західно-Українська Народна Республіка. 1918-1923. Док. і матер. : у 5 т....... Т. 2. С. 359.

${ }^{17}$ Там само. С. 408.

18 Там само.

19 Там само.

${ }^{20}$ Мироненко О. Національні меншини у ЗУНР... С. 332.

${ }^{21}$ Кульчицький В. С., Тищик Б. Й. Історія держави і права України : навч. посіб. Київ : Атіка, 2001. C. 174.

${ }^{22}$ Великочий В. Національно-культурна політика ЗУНР у контексті українсько-польських відносин... C. 269.

${ }^{23}$ Кульчицький В. С., Тищик Б. Й. Історія держави і права України... С. 175.

24 Західно-Українська Народна Республіка. 1918-1923. Док. і матер. : у 5 т. Т. 2.... С. 550-564, 566, 569, $571-572$.

${ }^{25}$ Там само. С. 575 ; Косів М. Воскресають лише там, де є могили... Дзвін. 1990. № 6. С. 93.
} 
народности. Щонайменше один віце-президент має бути польської і один - жидівської народности”. У ст. IX (“Національні права"), в артикулі 22 констатовано, що “школи народні й середні мають бути зорганізовані в міру потреби, зокрема, для всіх трьох головних національностей та наука в сих школах мається подавати у матірній мові учеників”, в артикулі 23,що "внутрішньою мовою урядовою для всіх державних урядів Галицької Республики є мова українська", що “урядниками й службовиками в Галицькій Республиці можуть бути іменовані лише горожане держави, що володіють найменше двома мовами національностей держави",26 (тобто українською і польською або українською і єврейською).

Про інтереси національних меншин ішлося й в інших законопроектах. Так, наприкінці 1920 р. на замовлення уряду ЗУНР правник С. Дністрянський підготував проект Конституції ЗУНР. Найвищим органом влади Республіки мала бути народна палата, обрана на 4 роки на підставі загального, безпосереднього, рівного й таємного голосування. Згідно 3 принципом самовизначення послів народної палати розподілено на 3 національні курії: українську, польську та курію інших національностей. Наприкінці проекту встановлено норми самовизначення народів ЗУНР. Меншинам також гарантовано основні права (автономія, культура, школи, преса) та представництво в органах влади за ключем 4:1:1 (4 українці, 1 поляк та 1 представник іншої національності) ${ }^{27}$.

Традиційно в правовому полі тривала реалізація мовних прав національних меншин у ЗУНР. Так, згідно з Законом про мови від 15 лютого 1919 р., державною мовою проголошено українську. Однак “законно признаним національним меншостям”, тобто полякам, євреям і німцям, було надано право вільно користуватися рідною мовою в офіційних зносинах 3 органами влади, громадськими інституціями, державними підприємствами ${ }^{28} .3$ цього випливало, що чиновники зобов'язані були відповідати громадянам неукраїнської національності - усно та письмово - їхньою рідною мовою: польською, єврейською чи німецькою.

Значною мірою мовні права іноетнічне населення могло реалізувати і в освітній сфері. Наприклад, за Законом від 13 лютого 1919 р. "Про основи шкільництва" національним меншинам було дозволено відкривати школи з рідною мовою навчання ${ }^{29}$, а за шкільними адміністраціями визнавали “право прилюдності” 30 , тобто вони могли видавати вихованцям атестати про здобуття освіти. Разом із цим, постановою Державного секретаріату освіти і віросповідань від 23 лютого 1919 р. у школах з українською мовою навчання було відмінено обов’язкове вивчення польської мови. У тих школах, де вивчали німецьку мову, її курс обмежили двома тижневими годинами ${ }^{31}$ для закріплення вивченого. Українська мова як державна була обов'язковою навчальною дисципліною для всіх шкіл національних меншин ${ }^{32}$.

Підсумовуючи, варто відзначити, що етнополітика керівництва ЗУНР була демократичною. Новостворена УНРада 3 перших кроків діяльності не лише задекларувала визнання прав національних меншин, їхню громадянську, етнічну й віросповідну рівноправність, але й гарантувала їм національно-культурну автономію та представництво в уряді. Однак характерною особливістю окресленого хронотопу були важкі умови, викликані агресією з боку Польщі. Тому чимало заходів української влади нерідко залишалися декларативними через неможливість їхньої реалізації. Певну непослідовність проявляли й національні меншини, насамперед євреї і німці, котрі, дотримуючись нейтралітету в українсько-польській війні, істотно обмежували свою участь у державотворчих процесах.

\footnotetext{
26 Західно-Українська Народна Республіка. 1918-1923. Док. і матер. : у 5 т. Т. 2... С. 566, 569, 571-572.

27 Чехович В. Конституція Західноукраїнської Народної Республіки... С. 204.

28 Західно-Українська Народна Республіка. 1918-1923. Док. і матер. : у 5 т. Т. 2... С. 226.

${ }^{29}$ Там само. С. 220.

30 Західно-Українська Народна Республіка. 1918-1923. Док. і матер. : у 5 т. Т. 3, кн. 2... С. 649.

31 Західно-Українська Народна Республіка. 1918-1923. Док. і матер. : у 5 т. Т. 2... С. 258.

32 Там само. С. 155.
} 


\title{
NATIONAL MINORITIES IN THE CONTEXT OF THE STATE ETHNOPOLITICS OF THE ZUNR PERIOD
}

\author{
Mykola LAZAROVYCH \\ Ternopil National Economic University, \\ Department of Documentation Science, Information Activity and Ukrainian Studies \\ Lvivska st. 11, 46009, Ternopil, Ukraine, \\ e-mail:lazar-m@ukr.net
}

\begin{abstract}
Summary
The purpose of the article is to analyze and generalize the features and trends of the ethnonational policy of the ZUNR government in the conditions of the liberation struggle of 1918-1919.

The main activities of the Ukrainian authorities to ensure the rights and freedoms of the foreign ethnic population are investigated. The legal basis of state ethnopolitics is analyzed. The attitude of national minorities to the construction of the Ukrainian state is determined.

The prerequisites and the process of attracting representatives of the foreign ethnic population to practical activities for the development of Ukrainian statehood are investigated, the mechanism of national representation in government bodies is clarified, the structure and principles of their functioning are analyzed. It is summed up that the ethnopolitics of the ZUNR leadership was democratic, but the characteristic feature of the outlined chronotope was the difficult conditions caused by the aggression on the part of Poland.

Therefore, many events of the Ukrainian government often remained declarative due to the impossibility of their implementation. Involvement of the foreign population to participate in the representative and executive structures of the Ukrainian government was not only an integral part of its ethno-national policy, but also an important factor in the development of the state.

But national minorities, primarily Jews and Germans, showed a certain inconsistency and respecting neutrality in the Polish-Ukrainian war, significantly limited their participation in state processes.

Keywords: authorities, ethnonational policy, national minorities, rights and freedoms, legislation.
\end{abstract}

\section{REFERENCES}

Velykochyi V. Natsionalno-kulturna polityka ZUNR u konteksti ukrainsko-polskykh vidnosyn (19181919). Mizhnarodnyi naukovyi konhres "Ukrainska istorychna nauka na porozi XXI st.". Dopovidi ta povidomlennya. Chernivtsi, 16-18 travnia 2000 r. Chernivtsi, 2001. T. 2. S. 266-270. [in Ukrainian].

Hon M. Yevreyi v ZUNR: stratehiya, taktyka ta vplyv na formuvannia vzayemyn $\mathrm{z}$ ukraintsyamy $\mathrm{v}$ mizhvoiennyi period. Ukraina : kulturna spadshchyna, natsionalna svidomist, derzhavnist. 2009. Vyp. 18. S. 181-189. [in Ukrainian].

Zakhidno-Ukrainska Narodna Respublika. 1918-1923. Dok. i mater. : u 5 t. T. 1. Ivano-Frankivsk : Lileia-NV, 2001. 584 s. [in Ukrainian].

Zakhidno-Ukrainska Narodna Respublika. 1918-1923. Dok. i mater. : u 5 t. T. 2. Ivano-Frankivsk : Lileia-NV, 2003. 712 s. [in Ukrainian].

Zakhidno-Ukrainska Narodna Respublika. 1918-1923. Dok. i mater. : u 5 t. T. 3, kn. 2. IvanoFrankivsk : Lileia-NV, 2005. 680 s. [in Ukrainian].

Zakhidno-Ukrainska Narodna Respublika. 1918-1923 : iliustr. istoriia. Lviv ; Ivano-Frankivsk : Manuskrypt, 2008. 524 s.: il. [in Ukrainian].

Kohan S. Evrei v Zapadno-Ukrainskoi Narodnoy Respublike. Ukraina : kulturna spadshchyna, natsionalna svidomist, derzhavnist. 2009. Vyp. 18. S. 190-198. [in Ukrainian].

Kosiv M. Voskresaiut lyshe tam, de ye mohyly... Dzvin. 1990. № 6. S. 81-97. [in Ukrainian].

Kotliar Yu. V. Etnonatsionalni pytannia v Zakhidno-Ukrainskii Narodnii Respublitsi Ukraina : kulturna spadshchyna, natsionalna svidomist, derzhavnist. 2009. Vyp. 18. S. 175-180. [in Ukrainian].

Kulchytskyi V. S., Tyshchyk B. Y. Istoriia derzhavy i prava Ukrainy : navch. posib. Kyiv : Atika, 2001. 320 s. [in Ukrainian]. Ukrainian].

Makarchuk S. A. Ukrainska Respublika halychan : narysy pro ZUNR. Lviv : Svit, 1997. 192 s. [in

Lazarovych M. V. Etnopolityka ukrainskoi vlady doby natsionalno-vyzvolnykh zmahan 1917-1921 rokiv: komparatyvnyi analiz : monohr. Ternopil' : TNEU, 2013. 760 s. [in Ukrainian].

Myronenko O. Natsionalni menshyny u ZUNR. Mala entsyklopediia etnoderzhavoznavstva. Kyiv : Dovira ; Heneza, 1996. S. 332. [in Ukrainian].

Natsionalni menshyny Ukrainy u XX st.: polityko-pravovyi aspekt / M. Panchuk, V. Voinalovych, O. Halenko ta in. Kyiv, 2000. 357 s. [in Ukrainian]. 


\section{4 Галичина}

Pavlyshyn O. Yevreiske naselennia Skhidnoi Halychyny u 1918-1919 rr. : sotsialniy aspekt.

Halychyna. 2006-2007. Vyp. 12-13. S. 27-48. [in Ukrainian].

Pavlyshyn $O$. Orhanizatsiia tsyvilnoi vlady ZUNR u povitakh Halychyny (lystopad-hruden 1918 r.).

Ukraina moderna. 1999. Ch. 2-3. S. 132-193. [in Ukrainian].

Rafalskyi O. O. Natsionalni menshyny Ukrayiny u XX stolitti : istoriohraf. narys. Kyiv : Polius, 2000. 447 s. [in Ukrainian].

Riaboshapko L. I. Pravove stanovyshche natsionalnykh menshyn v Ukraini (1917-2000) : monohr. Lviv : Vyd. tsentr LNU im. I. Franka, 2001. 484 s. [in Ukrainian].

Chekhovych V. Konstytutsiia Zakhidnoukrainskoi Narodnoi Respubliky. Mala entsyklopediiya etnoderzhavoznavstva. Kyiv : Dovira ; Heneza, 1996. S. 203-204. [in Ukrainian].

Chekhovych V. Natsionalno polityka uryadu ZUNR. Mala entsyklopediia etnoderzhavoznavstva. Kyiv : Dovira ; Heneza, 1996. S. 325-326. [in Ukrainian].

Klimecki M. Polsko-ukrainska wojna o Lwow i Galicje Wschodnia 1918-1919. Warsawa : Oficyna

Wydawnicza Volumen, 2000. 292 s. [in Poland]. 